\title{
Metabolic Fates of Carbon Skeletons of Methionine, Serine, and Alanine in Growing Rats Fed Soybean Protein Diets
}

\author{
Hideyuki TaNaKa, Junichiro NAKaJima, Mitsuhiro MorI, \\ and Masaji OGURA \\ Department of Applied Biochemistry, Faculty of Agriculture, \\ Utsunomiya University, Utsunomiya 321, Japan \\ (Received June 10, 1994)
}

Summary The effects of dietary soybean protein isolate intakes on the metabolic fates of $\mathrm{L}-\left[\mathrm{U}-{ }^{14} \mathrm{C}\right]$ methionine, $\mathrm{L}-\left[\mathrm{U}-{ }^{14} \mathrm{C}\right]$ serine, and $\mathrm{L}-\left[\mathrm{U}-{ }^{14} \mathrm{C}\right]-$ alanine were investigated in growing rats. In the growth experiment for 21 days, body weight gain reached a plateau at more than 20 protein calorie percent (PC\%) in the diet, and the protein efficiency ratio attained maximum in the $10 \mathrm{PC} \%$ group. Carcass and liver lipid contents increased greatly in the lower levels of dietary soybean protein, which was associated with their decrease in moisture contents. In the isotope experiments, the incorporation of ${ }^{14} \mathrm{C}$ into the body protein $12 \mathrm{~h}$ after the injection of $\left[{ }^{14} \mathrm{C}\right]$ methionine was extremely high (more than $80 \%$ of the dose) in the 5 to 15 PC\% groups, but decreased thereafter in the higher PC\% groups. The expired ${ }^{14} \mathrm{CO}_{2}$ production from $\left[{ }^{14} \mathrm{C}\right]$ methionine was depressed in the lower PC\% groups, and thereafter it increased with increasing levels of dietary protein, showing a break point at around 20 PC\%. The carbon skeleton of $\left[{ }^{14} \mathrm{C}\right]$ alanine was extensively oxidized to ${ }^{14} \mathrm{CO}_{2}$, even in protein-depleted rats, while serine carbon was utilized for body protein synthesis rather than for energy production. These results indicate that methionine, which is a limiting amino acid of soybean protein for rats, is preferentially utilized for body protein synthesis especially in protein-depleted rats, and the metabolic responses of methionine, serine, and alanine are quite different from each other.

Key Words soybean protein, methionine, serine, alanine, metabolic fate of amino acids

Amino acids are primarily utilized for body protein synthesis, but when amino acids are supplied in excess their carbon skeletons are oxidized to carbon dioxide or converted to glucose or fat for energy metabolism (1). In previous studies, the metabolic fates of carbon skeletons of individual amino acids have been examined in growing rats fed diets with graded levels of a purified whole egg protein using ${ }^{14} \mathrm{C}$-labeled amino acids $(2-11)$. These experimental results show that the metabolic 
aspect of 20 individual amino acids are classified into three groups. The first one includes nonessential amino acids, such as alanine and glutamic acid, which are rapidly oxidized to expired carbon dioxide but incorporated to a lesser extent into the body protein, the second includes nonessential amino acids, such as serine and proline, which are used for body protein synthesis rather than for energy production, and the third includes essential amino acids that are efficiently used for body protein synthesis. By using the purified whole egg protein as a dietary protein source, it was possible to investigate the effects of dietary protein to energy ratios on the metabolic fates of amino acids without inappropriate factors such as limiting amino acids.

Soybean is one of the important food articles consumed in large quantities in various forms, and the nutritional quality of soybean protein has been extensively studied (12-16). Although for children and adults methionine supplementation to soybean protein diets is not only unnecessary but may even be undesirable under conditions of normal usage (15), it is well confirmed that methionine is the most limiting essential amino acid for rats (14). Although many studies on growth and nitrogen balance show that soybean protein has adverse effect for the optimum growth for rats, the metabolic response of amino acids to soybean protein intake has not been sufficiently clarified. It is of interest whether the response pattern of essential or nonessential amino acids varies with the ingestion of diets containing disproportionate amounts of amino acids. In this study, to investigate the effect of quality and quantity of dietary proteins on the metabolism of carbon skeletons of individual amino acids, we examined the distribution of radioactivity after injecting ${ }^{14} \mathrm{C}$-labeled methionine, serine, and alanine in growing rats fed the diets with a graded level of soybean protein isolate. The results obtained are compared to those with the purified whole egg protein diet in the previous experiments $(2,3,9)$.

\section{MATERIALS AND METHODS}

Growth experiments (Expt. 1). Male weanling Wistar rats were preliminarily fed a stock diet (Oriental ME) until the mean body weight reached about $90 \mathrm{~g}$. The animals were housed in individual stainless wire-mesh cages at $23 \pm 1^{\circ} \mathrm{C}$ in a temperature-controlled room with a 12 -h light $(06: 00$ to $18: 00)$ cycle. The animals were divided into 7 groups $(0,5,10,15,20,30$, and 40 PC $\%$ groups) of 6 animals each. The composition of the experimental diets with a graded level of soybean protein isolate (Fujipro R, Fuji Oil Co.) is shown in Table 1. The protein calorie percentage ( $\mathrm{PC} \%$ ) means the proportion of metabolizable energy of dietary protein to the total metabolizable energy of the diets (17), i.e. $4,100 \mathrm{kcal} / \mathrm{kg}$ of diet in this experiment. Food and water were given ad libitum for 21 days. Body weight and food consumption were recorded on alternate days during the experimental period.

At the end of the experiment, the animals were killed by decapitation, the intact liver was removed, and the shed blood was combined with the carcass. The 
Table 1. Composition of experimental diets (dry $\mathrm{g} / \mathrm{kg}$ diet).

\begin{tabular}{lrrrcccc}
\hline \multirow{2}{*}{ Ingredients } & \multicolumn{7}{c}{ Dietary groups (PC\%) } \\
\cline { 2 - 8 } & \multicolumn{1}{c}{0} & \multicolumn{1}{c}{5} & 10 & 15 & 20 & 30 & 40 \\
\hline Soybean protein $^{2}$ & 0 & 56 & 113 & 169 & 225 & 338 & 450 \\
Cornstarch $^{1}$ & 800 & 744 & 687 & 631 & 575 & 462 & 350
\end{tabular}

Lard, 100; salt mixture, ${ }^{3} 40$; vitamin mixture, ${ }^{3} 10$; cellulose powder, ${ }^{4} 50$; metabolizable energy $(\mathrm{kcal} / \mathrm{kg}), 4100$

${ }^{1}$ Protein calorie percentage (metabolizable energy of protein per total metabolizable energy of the diets). ${ }^{2}$ Fujipro R, Fuji Oil Co. Ltd. (protein content, 95\%). ${ }^{3}$ Oriental Yeast Co. Ltd. ${ }^{4}$ Toyo Roshi Co. Ltd.

liver and carcass were homogenized, and analyzed for moisture by lyophilization, for protein content by the Kjeldahl method, and for lipid content by chloroformmethanol extraction as described previously (18).

Isotope experiments (Exp. 2). Male Wistar rats weighing about $80 \mathrm{~g}$ were divided into 5 groups of 4 animals each, and fed the soybean protein diets with 5 , $10,15,20$, and 30 or $40 \mathrm{PC} \%$. Food and water were given ad libitum for 10 days. On the last day of feeding, the rats were starved for $9 \mathrm{~h}$, from $12: 00$ to $21: 00$, and then given the same experimental diets for $3 \mathrm{~h}$, from $21: 00$ to $24: 00$. After this feeding, ${ }^{14} \mathrm{C}$-labeled amino acid in a saline solution was injected intraperitoneally. $\mathrm{L}-\left[\mathrm{U}-{ }^{14} \mathrm{C}\right]$ Methionine $(9.99 \mathrm{GBq} / \mathrm{mmol}), \mathrm{L}-\left[\mathrm{U}-{ }^{14} \mathrm{C}\right]$ serine $(6.33 \mathrm{GBq} / \mathrm{mmol})$, and $\mathrm{L}-$ [U- ${ }^{14} \mathrm{C}$ ]alanine $(5.99 \mathrm{GBq} / \mathrm{mmol})$ were purchased from Amersham, Japan. The standard dosage was $48.5 \mathrm{kBq} / 0.4 \mathrm{ml} / 100 \mathrm{~g}$ of body weight for labeled methionine, $63.6 \mathrm{kBq}$ for labeled serine, and $134.2 \mathrm{kBq}$ for labeled alanine. Immediately after the injection, each animal was placed in a glass metabolism apparatus, and given only water. The expired carbon dioxide was collected in a mixture of monoethanolamine and ethyleneglycol monomethyl ether $(1: 2, \mathrm{v} / \mathrm{v})$ for $12 \mathrm{~h}$, and the radioactivity was measured by the method of Jeffay and Alvarez (19). Urine was collected in $5 \%$ acetic acid for $12 \mathrm{~h}$, and the radioactivity was measured in an NT (nonion-toluene) scintillation solution containing $4 \mathrm{~g}$ of PPO per liter of 3 parts of nonylphenoxy polyethoxy ethanol and 7 parts of toluene (20).

The animals were killed by decapitation $12 \mathrm{~h}$ after administering the isotopes. The liver was removed, and the shed blood was combined with the carcass. The carcass and liver were homogenized and analyzed for radioactivity in their major components such as the protein, lipid, and soluble fractions, details of which were described previously (6). A portion of the homogenate was extracted with a chloroform-methanol mixture $(2: 1, \mathrm{v} / \mathrm{v})$ to obtain the lipid fraction, and then the residue was extracted with cold 10\% trichloroacetic acid (TCA). The extract was combined with the upper phase solution by Folch's washing method (21) to obtain the soluble fraction of the sample. The TCA insoluble residue was dissolved in a $2 \mathrm{~N}$ $\mathrm{NaOH}$ solution as the protein fraction. The radioactivity of the protein and soluble 
fractions was measured in an NT scintillation solution. The radioactivity of the lipid fraction was measured in a toluene scintillation solution containing $4 \mathrm{~g}$ of PPO and $0.5 \mathrm{~g}$ of POPOP per liter of toluene. The radioactivity was measured in a liquid scintillation spectrometer (Aloka, LSC-900). The efficiency of the counting system was estimated for each sample by an external standard ratio method.

In the experiments for $\left[{ }^{14} \mathrm{C}\right]$ methionine and $\left[{ }^{14} \mathrm{C}\right]$ serine, the tissue protein was hydrolyzed with $6 \mathrm{~N} \mathrm{HCl}$ at $110^{\circ} \mathrm{C}$ for $24 \mathrm{~h}$ in a sealed tube, and amino acids in the hydrolysate were analyzed in an amino acid analyzer (JEOL, 6AHS). The effluent of the column was divided into two streams, the first one was used to detect the amino acids by the ninhydrin reaction and the second to measure the radioactivity.

Statistical analysis. The results were tested by analysis of variance, and Tukey's test for multiple comparisons was used to evaluate the statistical significance with a probability level of $0.05(22)$.

\section{RESULTS}

\section{Growth experiment (Expt. 1)}

The growth curves of the dietary groups of more than $20 \mathrm{PC} \%$ were almost linear, while those of the 10 and 15 PC\% groups were retarded during the early days of the experimental period (Fig. 1). Body weight gain, food efficiency (gain per intake), and the protein efficiency ratio for the entire period of the experiment are shown in Table 2. Body weight gain reached an approximate plateau of $7 \mathrm{~g}$ per day in the $20 \mathrm{PC} \%$ group, and the rats fed the 5 PC\% soybean protein diet barely maintained their weight gains. Food efficiency attained a plateau of about 0.5 in the dietary groups of more than $20 \mathrm{PC} \%$, and the protein efficiency ratio showed a maximum of 2.4 in the $10 \mathrm{PC} \%$ group. The protein efficiency ratio tended to

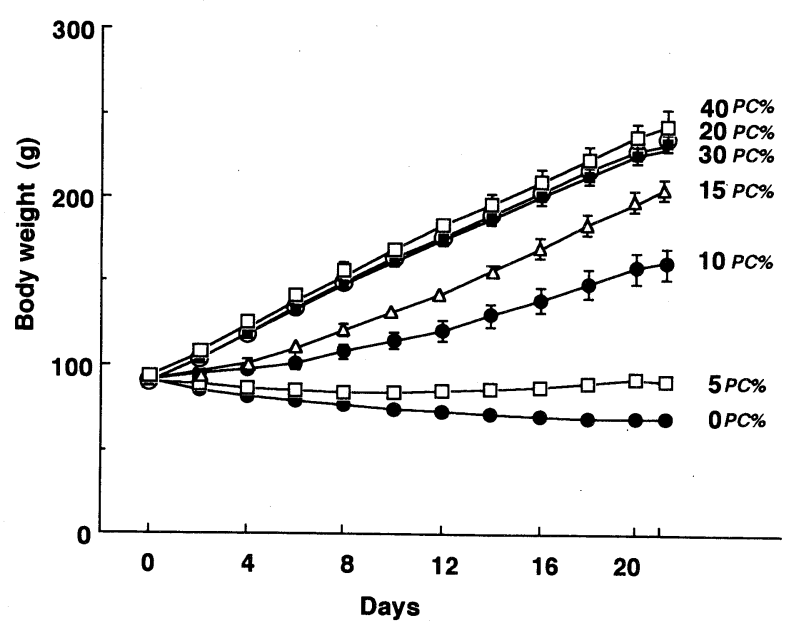

Fig. 1. Growth curves of growing rats fed the diets with graded levels of soybean protein for 21 days. Each point indicates the mean $\pm \mathrm{SE}$ for six rats. 
Table 2. Body weight gain, food efficiency, and protein efficiency ratio (PER) in growing rats fed the diets with graded levels of soybean protein for 21 days.

\begin{tabular}{ccccc}
\hline $\begin{array}{c}\text { Groups } \\
(\text { PC\% })\end{array}$ & $\begin{array}{c}\text { Body weight gain } \\
\text { (g/day) }\end{array}$ & $\begin{array}{c}\text { Food intake } \\
(\mathrm{g} / 21 \text { days })\end{array}$ & Food efficiency & PER \\
\hline 0 & $-1.0 \pm 0.1$ & $89 \pm 5$ & $-0.25 \pm 0.02$ & - \\
5 & $0.1 \pm 0.2$ & $121 \pm 8$ & $0.00 \pm 0.03$ & $0.1 \pm 0.5$ \\
10 & $3.5 \pm 0.4$ & $277 \pm 19$ & $0.27 \pm 0.02$ & $2.4 \pm 0.2$ \\
15 & $5.4 \pm 0.3$ & $289 \pm 10$ & $0.39 \pm 0.01$ & $2.3 \pm 0.1$ \\
20 & $6.9 \pm 0.3$ & $313 \pm 16$ & $0.47 \pm 0.02$ & $2.1 \pm 0.1$ \\
30 & $6.8 \pm 0.2$ & $297 \pm 8$ & $0.48 \pm 0.02$ & $1.4 \pm 0.1$ \\
40 & $7.3 \pm 0.4$ & $290 \pm 7$ & $0.53 \pm 0.02$ & $1.2 \pm 0.1$ \\
Dif. & 1.2 & 50 & 0.09 & 0.9 \\
\hline
\end{tabular}

The values are means \pm SE for six rats. "Dif." values indicate significant differences $(p<0.05)$ among the means.

Table 3. Carcass and liver compositons in growing rats fed the diets with graded levels of soybean protein for 21 days.

\begin{tabular}{cccccccc}
\hline \multirow{2}{*}{$\begin{array}{l}\text { Groups } \\
\text { (PC\%) }\end{array}$} & \multicolumn{3}{c}{ Carcass composition } & & \multicolumn{3}{c}{ Liver composition } \\
\cline { 2 - 3 } \cline { 6 - 8 } & Moisture & Protein & Lipid & & Moisture & Protein & Lipid \\
& $(\%)$ & $(\%)$ & $(\%)$ & & $(\%)$ & $(\%)$ & $(\%)$ \\
\hline 0 & $66.4 \pm 0.4$ & $18.2 \pm 0.2$ & $10.3 \pm 0.6$ & & $68.0 \pm 1.2$ & $12.9 \pm 0.6$ & $8.4 \pm 0.5$ \\
5 & $61.4 \pm 0.5$ & $17.5 \pm 0.2$ & $16.3 \pm 0.6$ & & $65.9 \pm 1.1$ & $11.5 \pm 1.5$ & $11.5 \pm 1.6$ \\
10 & $56.8 \pm 0.9$ & $15.5 \pm 0.4$ & $23.2 \pm 1.0$ & & $69.4 \pm 0.3$ & $16.3 \pm 0.4$ & $5.9 \pm 0.6$ \\
15 & $58.9 \pm 1.1$ & $17.0 \pm 0.4$ & $19.6 \pm 1.0$ & & $69.5 \pm 0.2$ & $18.0 \pm 0.3$ & $5.2 \pm 0.3$ \\
20 & $58.5 \pm 0.8$ & $17.0 \pm 0.3$ & $19.8 \pm 0.8$ & & $68.9 \pm 0.2$ & $18.7 \pm 0.2$ & $5.8 \pm 0.2$ \\
30 & $62.2 \pm 1.2$ & $18.9 \pm 0.4$ & $13.8 \pm 0.4$ & & $68.7 \pm 0.1$ & $19.4 \pm 0.5$ & $5.1 \pm 0.2$ \\
40 & $63.4 \pm 0.6$ & $19.2 \pm 0.3$ & $14.7 \pm 1.9$ & & $68.8 \pm 0.1$ & $20.8 \pm 0.2$ & $4.9 \pm 0.1$ \\
Dif. & 3.6 & 1.5 & 4.4 & & 3.6 & 1.5 & 3.5 \\
\hline
\end{tabular}

The values are means \pm SE for six rats. "Dif." values indicate significant differences $(p<0.05)$ among the means.

decrease gradually at higher levels of dietary protein, which is consistent with previous observations $(18,23)$. As for carcass composition (Table 3), the greatest decrease in moisture content was found in the $10 \mathrm{PC} \%$ group accompanied by the largest increase in lipid content. In general, the increase or decrease of moisture content was associated with the decrease or increase of tissue lipid content, as has been reported $(13,24)$. Carcass lipid content gave a blunt peak in the 5 to $20 \mathrm{PC} \%$ groups. The decreased content of carcass protein in the lower PC\% groups was also due to the increase of lipid content. As for liver composition, the lipid content increased significantly in the $5 \mathrm{PC} \%$ group with a single sharp peak, in contrast to the case of carcass lipids. The protein content increased gradually in the higher PC\% groups. Thus, the body composition was greatly affected by the different 
protein to energy ratios of the diets, showing a specific accumulation of liver lipids in the low-protein diets.

\section{Matabolic fates of amino acids (Expt. 2)}

In the isotope experiments, the rats were fed on the diets with a graded level of soybean protein during 10 days. The growth rates were essentially identical with those obtained in the growth experiments for 21 days, except that the growth in the $20 \mathrm{PC} \%$ group was somewhat retarded in the isotope experiments for 10 days. Since only a trace of the labeled amino acid was used, no drastic change of pool size of the amino acid in the tissues was induced by the injection of the isotope, as has been pointed out (2). Total recovery percentages of the radioactivity were 99 to $107 \%$ for $\left[{ }^{14} \mathrm{C}\right]$ methionine, 89 to $94 \%$ for $\left[{ }^{14} \mathrm{C}\right]$ serine, and 93 to $99 \%$ for $\left[{ }^{14} \mathrm{C}\right]-$ alanine (the means of four rats in each group).

Table 4. Distribution of radioactivity in the protein, lipid, and soluble fractions of carcass and liver after the injection of $\mathrm{L}-\left[\mathrm{U}-{ }^{14} \mathrm{C}\right]$ methionine, $\mathrm{L}-\left[\mathrm{U}-{ }^{14} \mathrm{C}\right]$ serine, and $\mathrm{L}-$ $\left[\mathrm{U}-{ }^{14} \mathrm{C}\right]$ alanine in growing rats fed the diets with graded levels of soybean protein.

\begin{tabular}{|c|c|c|c|c|c|c|}
\hline \multirow{3}{*}{$\begin{array}{l}\text { Dietary } \\
\text { groups } \\
\text { (PC\%) }\end{array}$} & \multicolumn{6}{|c|}{$\%$ of the injected dose } \\
\hline & \multicolumn{2}{|c|}{ Protein } & \multicolumn{2}{|c|}{ Lipid } & \multicolumn{2}{|c|}{ Soluble fraction } \\
\hline & Carcass & Liver & Carcass & Liver & Carcass & Liver \\
\hline \multicolumn{7}{|c|}{ L- $\left[\mathrm{U}-{ }^{14} \mathrm{C}\right]$ Methionine } \\
\hline 5 & $70.4 \pm 2.4$ & $9.9 \pm 0.4$ & $2.2 \pm 0.2$ & $1.5 \pm 0.1$ & $7.7 \pm 0.6$ & $1.2 \pm 0.2$ \\
\hline 10 & $77.8 \pm 0.7$ & $9.5 \pm 0.5$ & $1.6 \pm 0.0$ & $1.1 \pm 0.0$ & $7.7 \pm 0.6$ & $0.8 \pm 0.0$ \\
\hline 15 & $74.8 \pm 0.7$ & $8.1 \pm 0.4$ & $1.6 \pm 0.1$ & $1.1 \pm 0.1$ & $8.3 \pm 0.3$ & $0.8 \pm 0.1$ \\
\hline 20 & $67.5 \pm 1.2$ & $7.7 \pm 0.5$ & $2.0 \pm 0.1$ & $1.3 \pm 0.1$ & $8.0 \pm 0.4$ & $0.9 \pm 0.1$ \\
\hline 30 & $64.0 \pm 1.2$ & $7.2 \pm 0.2$ & $3.7 \pm 0.5$ & $1.5 \pm 0.1$ & $8.2 \pm 0.7$ & $1.0 \pm 0.0$ \\
\hline Dif. & 6.0 & 1.8 & 1.1 & 0.4 & N.S. & N.S. \\
\hline \multicolumn{7}{|c|}{$\mathrm{L}-\left[\mathrm{U}-{ }^{14} \mathrm{C}\right]$ Serine } \\
\hline 5 & $36.8 \pm 0.6$ & $3.9 \pm 0.2$ & $5.2 \pm 0.2$ & $0.4 \pm 0.0$ & $9.9 \pm 0.5$ & $1.1 \pm 0.3$ \\
\hline 10 & $43.0 \pm 2.8$ & $3.5 \pm 0.1$ & $6.1 \pm 0.1$ & $0.4 \pm 0.0$ & $0.3 \pm 0.4$ & $1.2 \pm 0.3$ \\
\hline 15 & $39.2 \pm 0.5$ & $3.0 \pm 0.2$ & $7.0 \pm 0.5$ & $0.2 \pm 0.0$ & $7.6 \pm 0.3$ & $1.6 \pm 0.5$ \\
\hline 20 & $38.4 \pm 0.3$ & $3.0 \pm 0.1$ & $6.9 \pm 0.4$ & $0.1 \pm 0.0$ & $7.5 \pm 0.4$ & $1.5 \pm 0.2$ \\
\hline 30 & $39.9 \pm 1.0$ & $3.0 \pm 0.1$ & $5.4 \pm 0.5$ & $0.1 \pm 0.0$ & $8.8 \pm 0.6$ & $1.2 \pm 0.2$ \\
\hline Dif. & N.S. & N.S. & 1.6 & 0.1 & 2.0 & N.S. \\
\hline \multicolumn{7}{|c|}{$\mathrm{L}-\left[\mathrm{U}-{ }^{14} \mathrm{C}\right]$ Alanine } \\
\hline 5 & $8.0 \pm 1.5$ & $1.0 \pm 0.3$ & $10.5 \pm 2.2$ & $0.21 \pm 0.3$ & $3.3 \pm 0.4$ & $0.8 \pm 0.3$ \\
\hline 10 & $8.7 \pm 0.7$ & $0.8 \pm 0.1$ & $15.5 \pm 1.7$ & $0.23 \pm 0.0$ & $3.9 \pm 0.9$ & $0.7 \pm 0.1$ \\
\hline 15 & $7.2 \pm 0.7$ & $0.7 \pm 0.2$ & $29.6 \pm 5.5$ & $0.08 \pm 0.2$ & $2.6 \pm 0.1$ & $1.2 \pm 0.4$ \\
\hline 20 & $8.9 \pm 0.2$ & $1.2 \pm 0.1$ & $20.2 \pm 1.7$ & $0.05 \pm 0.1$ & $3.1 \pm 0.3$ & $1.4 \pm 0.3$ \\
\hline 40 & $11.3 \pm 0.4$ & $1.1 \pm 0.1$ & $12.5 \pm 1.0$ & $0.04 \pm 0.4$ & $3.4 \pm 0.2$ & $2.2 \pm 0.2$ \\
\hline Dif. & 3.8 & N.S. & 12.6 & 0.1 & N.S. & 1.2 \\
\hline
\end{tabular}

The values are means $\pm \mathrm{SE}$ for four rats. "Dif." values indicate significant differences $(p<0.05)$ among the means. N.S., not significant. 

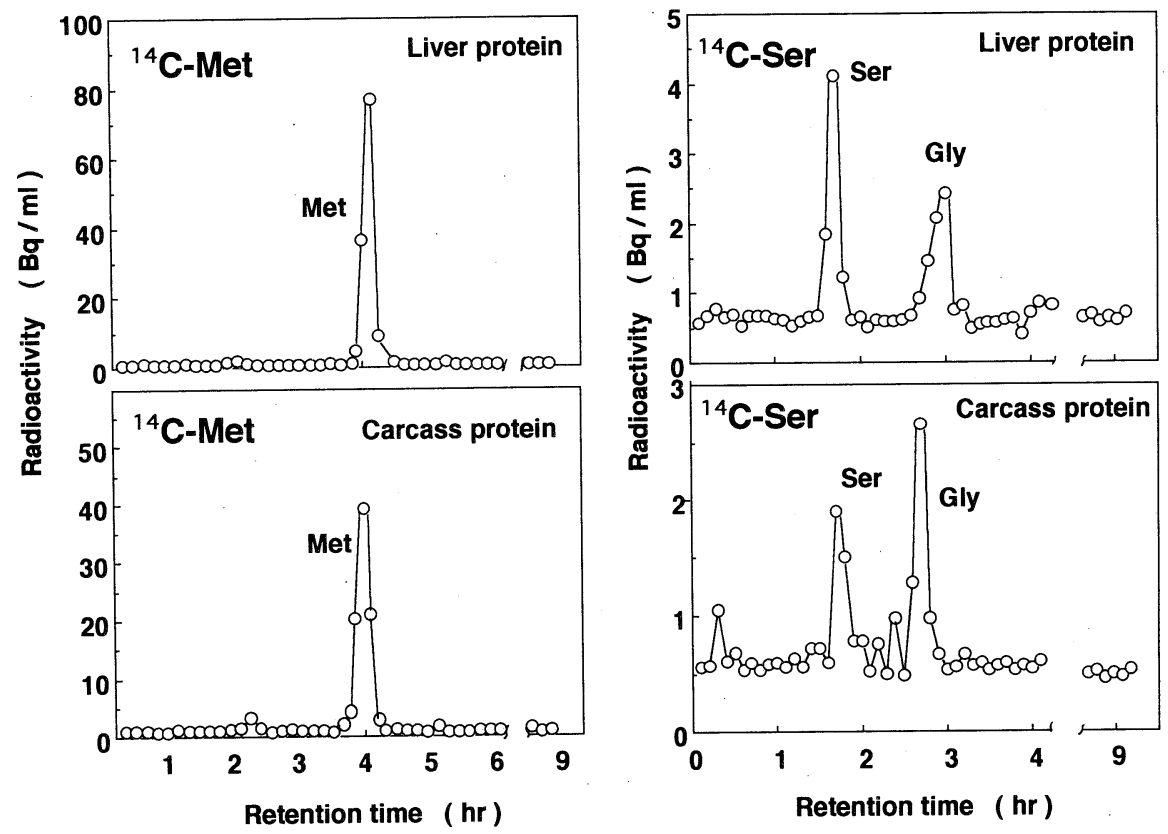

Fig. 2. Distribution of radioactivity in each amino acid fraction from protein hydrolysates of carcass and liver after injecting $\mathrm{L}-\left[\mathrm{U}-{ }^{14} \mathrm{C}\right]$ methionine and $\mathrm{L}$ $\left[\mathrm{U}-{ }^{14} \mathrm{C}\right]$ serine. The pooled sample for the carcass and liver protein hydrolysates in each group was fractionated by an automatic amino acid analyzer using a lithium citrate buffer system. Two milliliter fractions were collected from 0 to $4.5 \mathrm{~h}$, and then $4 \mathrm{ml}$ for 4.5 to $9.5 \mathrm{~h}$. One milliliter of each fraction was taken for the measurement of radioactivity.

The distribution of radioactivity in the protein, lipid, and soluble fraction of the carcass and liver $12 \mathrm{~h}$ after injecting the $\left[{ }^{14} \mathrm{C}\right]$ amino acids is shown in Table 4. The incorporation of radioactivity from $\left[{ }^{14} \mathrm{C}\right]$ methionine into the carcass protein was more than $70 \%$ of the injected dose in the 5 to $15 \mathrm{PC} \%$ groups, but it decreased in the higher PC\% groups. The incorporation of labeled methionine into the liver protein gradually decreased with increasing level of the soybean protein in the diets. The conversion of methionine carbon into the carcass lipid was about 1.6 to $3.7 \%$ of the dose. The values for the carcass and liver lipid were somewhat decreased in the 10 and 15 PC\% groups, and slightly increased in the lower and higher PC\% groups. The recovery of radioactivity in the carcass soluble fraction from labeled methionine was about $8 \%$ of the dose, and no significant differences were observed among the dietary groups. The distribution of radioactivity in each amino acid fraction after hydrolyzing the carcass and liver protein was examined. Typical elution patterns for $\left[{ }^{14} \mathrm{C}\right]$ methionine in the $15 \mathrm{PC} \%$ group are shown in Fig. 2. A large peak of radioactivity was detected only in the methionine fraction, and negligible quantities of radioactivity were detected in any of the other amino acid 


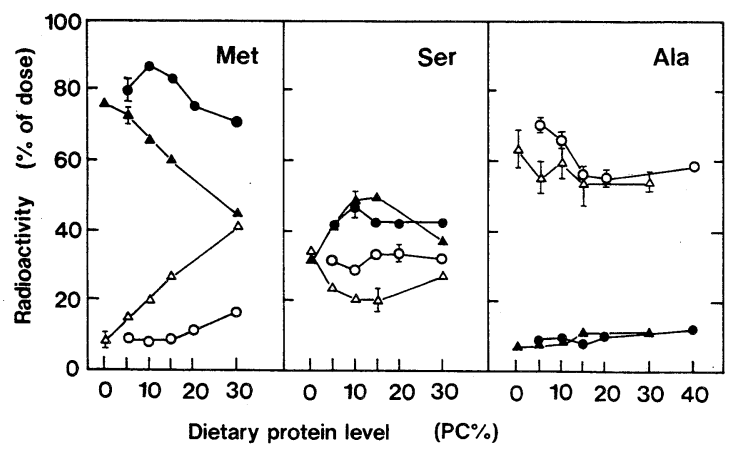

Fig. 3. Gross distribution of radioactivity in expired carbon dioxide and body protein after the injection of $\mathrm{L}-\left[\mathrm{U}_{-}-{ }^{14} \mathrm{C}\right]$ methionine, $\mathrm{L}-\left[\mathrm{U}-{ }^{14} \mathrm{C}\right]$ serine, and $\mathrm{L}-[\mathrm{U}-$ ${ }^{14} \mathrm{C}$ ]alanine in growing rats fed the diets with graded levels of soybean protein or purified whole egg protein. $\bigcirc$, expired $\mathrm{CO}_{2}$ with soybean protein diets; $\bullet$, body protein with soybean protein diets; $\triangle$, expired $\mathrm{CO}_{2}$ with whole egg protein diets; $\Delta$, body protein with whole egg protein diets. Mean \pm SE of 3 to 4 rats. The data for purified whole egg protein diets are cited and recalculated from references $(2,3,9)$.

fractions. When the protein hydrolysate from a pooled sample of each dietary group was analyzed in the same manner, no remarkable change in the elution pattern of radioactivity was observed among the dietary groups.

The incorporation of $\left[{ }^{14} \mathrm{C}\right]$ serine into the carcass protein was about $40 \%$ of the dose in all dietary groups (Table 4), and the values for the carcass plus liver protein were greater than those for the expired ${ }^{14} \mathrm{CO}_{2}$ production (Fig. 3). The conversion of serine carbon into the carcass lipid was high in the $15 \mathrm{PC} \%$ group, and the values in the lower and higher PC\% groups decreased slightly but significantly. As has been pointed out previously $(9,25)$, a part of the label incorporated into the tissue lipid fraction from methionine and serine might be due to the fractions of phospholipids, phosphatidylcholine and its derivatives. The recovery of radioactivity in the carcass soluble fraction from labeled serine was less than $10 \%$ of the dose, and the value was significantly increased in the lower PC\% groups. More than 50\% of the radioactivity recovered in the soluble fraction was mainly associated with the free amino acid fraction, serine and glycine, and about 30\% was found in a neutral fraction which non-adsorbed with both the Dowex 50 and Dowex 1 ion exchange resins (data not shown). The distribution of radioactivity in each amino acid fraction for the carcass and liver protein after injecting $\left[{ }^{14} \mathrm{C}\right]$ serine was also examined (Fig. 2). The radioactivity was not detected in any amino acid fractions except in serine and glycine. About $60 \%$ of the radioactivity incorporated into the carcass protein was associated with the serine fraction, but about $40 \%$ was found in the glycine fraction. No remarkable change in the elution pattern of radioactivity was observed among the dietary groups.

The incorporation of $\left[{ }^{14} \mathrm{C}\right]$ alanine into the carcass and liver protein was 
extremely low, and was almost unchanged with varying of the dietary protein calories percentages (Table 4). The conversion of alanine carbon into the tissue lipid was higher than those of methionine and serine carbons, and the value for the carcass lipid was increased in the 15 PC\% group but decreased significantly in the lower and higher PC\% groups. The recovery of radioactivity in the carcass soluble fraction from labeled alanine was 3 to $4 \%$ of the dose, and no significant differences were observed among the dietary groups. The value for the liver soluble fraction was somewhat increased in the higher PC $\%$ groups.

The ${ }^{14} \mathrm{CO}_{2}$ production from these labeled amino acids for $12 \mathrm{~h}$ after the injection of the isotopes is shown in Fig. 3. The patterns are compared to those obtained in the purified whole egg protein diets which were reported previously (2, $3,9)$. The gross distribution of the radioactivity incorporated into the body protein (carcass plus liver) is also shown. The ${ }^{14} \mathrm{CO}_{2}$ production after injecting labeled methionine is low in the 5 to $15 \mathrm{PC} \%$ groups, but thereafter it increased in the higher $\mathrm{PC} \%$ groups, about $16 \%$ of the dose being recovered in the $30 \mathrm{PC} \%$ group. The ${ }^{14} \mathrm{CO}_{2}$ production from labeled serine was almost unchanged with varying of the dietary levels of soybean protein, about $30 \%$ of the dose being recovered. The ${ }^{14} \mathrm{CO}_{2}$ production from labeled alanine was significantly greater than that from serine or methionine over the whole range of dietary protein levels, and even on a protein-free diet, alanine carbon was markedly oxidized to carbon dioxide (about $70 \%$ of the dose). The excretion of the radioactivity into a 12-h urine sample of rats was less than $2 \%$ of the dose of $\left[{ }^{14} \mathrm{C}\right]$ methionine, and no remarkable changes were observed among the dietary groups. The urinary excretion for $\left[{ }^{14} \mathrm{C}\right]$ serine $(1$ to $2 \%$ of the dose) and $\left[{ }^{14} \mathrm{C}\right]$ alanine $(0.5$ to $3.5 \%$ of the dose) were low in the lower PC\% groups, but it increased in the higher PC\% groups (data not shown).

\section{DISCUSSION}

In a series of our studies, the nutritional significance of metabolic fates of individual amino acids has been investigated in growing rats at various dietary protein calorie percentages by measuring the distribution of radioactivity from the ${ }^{14} \mathrm{C}$-labeled amino acids to the expired carbon dioxide, urine, body protein, body lipid, and body soluble fractions. In the present experiment, the growth, body composition, and efficiency of protein utilization were first investigated, serving as a guide to dietary conditions by use of soybean protein isolate as dietary protein source. A maximal value for the growth and the food efficiency was obtained at around $20 \mathrm{PC} \%$ in the soybean protein diet, although when the purified whole egg protein was used the maximum growth was obtained at around $10 \mathrm{PC} \%$ in the diet, as reported in the previous paper (18). Subsequently, the metabolic fates of the carbon skeletons of $\left[{ }^{14} \mathrm{C}\right]$ methionine, $\left[{ }^{14} \mathrm{C}\right]$ serine, and $\left[{ }^{14} \mathrm{C}\right]$ alanine in the soybean protein diets were examined and compared to those obtained for the whole egg protein diets which were reported previously $(2,3,9)$. When rats were fed on the soybean protein diets the expired ${ }^{14} \mathrm{CO}_{2}$ from labeled methionine was depressed in 
the lower PC\% groups but it increased markedly at higher PC\%, showing a break point at around $20 \mathrm{PC} \%$, whereas when rats were fed on the purified whole egg protein diets the expired ${ }^{14} \mathrm{CO}_{2}$ from methionine linearly increased with increasing the dietary protein intakes (Fig. 3). Peng et al. (26) reported that the production of expired ${ }^{14} \mathrm{CO}_{2}$ from methionine was low in a low casein diet, but increased in a high casein diet. Aguilar et al. (27) also reported that the expired ${ }^{14} \mathrm{CO}_{2}$ from methionine was linearly increased with increasing dietary levels from 30 to $120 \%$ of the estimated requirement of methionine, and this amino acid was oxidized at a much higher rate than the other essential amino acids. In this experiment, the incorporation of methionine carbon into body protein was high in the low protein diets, and it decreased with increasing the dietary protein levels. The values for the soybean protein diets were much higher than those for the whole egg protein diets over the whole range of dietary portein levels. No remarkable changes in the pattern for the metabolic response of serine or alanine carbons were observed between the rats fed on the soybean protein diets and on the whole egg protein diets. The incorporation of $\left[{ }^{14} \mathrm{C}\right]$ alanine into the body protein was markedly less in all the dietary groups, but the incorporation of $\left[{ }^{14} \mathrm{C}\right]$ serine was about $40 \%$ of the dose. The response of the expired ${ }^{14} \mathrm{CO}_{2}$ from serine to the dietary soybean protein intakes was not changed significantly, while in the growth experiments body weight gain attained a maximum at $20 \mathrm{PC} \%$ in the diet. The conversion of alanine carbon to the body lipid which was increased at 15 PC $\%$ in the diets, about $30 \%$ of the dose being recovered, was greater than the incorporation into the body protein. Thus, it was found that the carbon skeleton of the essential amino acid, methionine, was preferentially utilized for body protein synthesis, but the carbon skeleton of the nonessential amino acid, alanine, was extensively utilized for energy production even in protein depletion, whereas a considerable amount of serine was rather incorporated into the body protein. The results also suggested that the metabolic fate of each of these amino acids were quite different from one another, showing a systematic pattern that is peculiar to their essentiality and catabolic activity.

Using ${ }^{14} \mathrm{C}$-labeled amino acids, the expired ${ }^{14} \mathrm{CO}_{2}$ is adapted to estimate the amino acid requirement and to assess the efficiency of utilization of individual amino acids $(27,28)$. The validity of this technique is based on the observation that when the amino acid in the diet is suboptimal and below the requirement, a large proportion of the carbon skeleton of the amino acid will be conserved and used for body protein synthesis. When the dietary supply exceeds the animal needs for protein synthesis, increased use of the carbon skeleton for alternative processes such as lipogenesis and gluconeogenesis, or increased oxidation to carbon dioxide may be expected. The pattern of expired ${ }^{14} \mathrm{CO}_{2}$ production from $\left[{ }^{14} \mathrm{C}\right]$ methionine showed a breakpooint at around $20 \mathrm{PC} \%$ of soybean protein in the diets. This may be accounted for because methionine limited the growth of young rats until soybean protein is supplied at around $20 \mathrm{PC} \%$ in the diets.

We thank to Prof. M. Yamaguchi for his suggestions. A part of this work was 
supported in part by a grant from the Research Committee of Soy Protein Nutrition (Japan).

\section{REFERENCES}

1) Munro, H. N. (1970): Regulation mechanism in protein metabolism, in Mammalian Protein Metabolism, Vol. IV, ed. by Munro, H. N., Academic Press, New York and London, pp. 101-108.

2) Tanaka, H., Yamaguchi, M., and Kametaka, M. (1975): Metabolism of leucine and alanine in growing rats fed the diets with various protein to energy ratios. Agric. Biol. Chem., 39, 507-514.

3) Tanaka, H., Yamaguchi, M., and Kametaka, M. (1976): Metabolism of serine in growing rats and chicks at various dietary protein levels. Agric. Biol. Chem., 40, 11191127 .

4) Tanaka, H., and Ogura, M. (1980): Metabolism of histidine in growing rats at various dietary protein levels. Agric. Biol. Chem., 44, 2343-2349.

5) Tanaka, H., Ohyama, M., and Ogura, M. (1984): Metabolism of arginine, proline and glutamic acid in growing rats at various dietary protein levels. Agric. Biol. Chem., 48, 2731-2738.

6) Tanaka, H., Nakatomi, Y., and Ogura, M. (1987): Metabolism of phenylalanine, tyrosine and aspartic acid in growing rats at various dietary protein levels. Agric. Biol. Chem., 51, 499-505.

7) Tanaka, H., Nakatomi, Y., and Ogura, M. (1987): Metabolism of glycine and threonine in growing rats at various dietary protein levels. Agric. Biol. Chem., 51, 3087-3093.

8) Tanaka, H., Fukusima, T., Nakatomi, Y., and Ogura, M. (1988): Metabolism of valine and isoleucine in growing rats at various dietary protein levels. Agric. Biol. Chem., 52, 811-817.

9) Tanaka, H., Nakatomi, Y., Mori, M., and Ogura, M. (1990): Metabolism of methionine and cysteine in growing rats at various dietary protein levels. Agric. Biol. Chem., 54, 2093-2099.

10) Tanaka, H., Nakatomi, Y., Takahashi, K., and Ogura, M. (1991): Metabolism of lysine and tryptophan in growing rats at various dietary protein levels. Agric. Biol. Chem., 55, 811-817.

11) Tanaka, H., Takahashi, K., Mori, M., and Ogura, M. (1991): Metabolism of asparagine and glutamine in growing rats at various dietary protein levels. Agric. Biol. Chem., 55, 1867-1872.

12) Standal, B. R. (1963): Nutritional value of proteins of Oriental soybean foods. $J$. Nutr., 81, 279-285.

13) Czarnowska-Misztal, E., Kunachowicz, H., and Klys, W. (1983): Effect of increased proportion of soy protein in diet on the development and on nitrogen metabolism in laboratory rats. Zywienie Czlowieka, 10, 87-108.

14) Lowe, C. M., Kotula, K. T., and Briggs, G. M. (1985): The protein quality (PER and NPR) of several powdered soybean protein food products in the rat. Natr. Rep. Int., 32, 547-557.

15) Young, V. R., Scrimshaw, N. S., Torun, B., and Viteri, F. (1979): Soybean protein in human nutrition: An overview. J. Am. Oil Chem. Soc., 56, 110-120.

Vol. 40, No. 6, 1994 
16) Young, V. R., Wayler, A., Garza, C., Steinke, F. H., Murray, E., Rand, W. M., and Scrimshaw, N. S. (1984): A long-term metabolic balance study in young men to assess the nutritional quality of an isolated soy protein and beef proteins. Am. J. Clin. Nutr., 39, 8-15.

17) Miller, D. S., and Payne, P. R. (1961): Problems in the prediction of protein values of diets. The influence of protein concentration. Br. J. Nutr., 15, 11-19.

18) Tanaka, H., Yamaguchi, M., and Kametaka, M. (1974): Body composition and utilization of protein and energy in growing rats at different dietary energy ratios by use of purified whole egg protein. Agric. Biol. Chem., 38, 1113-1120.

19) Jeffay, H., and Alvarez, J. (1961): Liquid scintillation counting of carbon-14. Use of ethanolamine-ethylene glycol monomethyl ether-toluene. Anal. Chem., 33, 612-615.

20) Kawakami, M., and Shimura, K. (1972): A new scintillator in liquid scintillation counting and a simplified method of sample preparation for determination of tritium and carbon-14. Radioisotopes, 23, 81-87.

21) Folch, J., Lee, M., and Sloane-Stanley, G. H. (1957): A simple method for the isolation and purification of total lipids from animal tissues. J. Biol. Chem., 226, 497509.

22) Yoshida, M. (1975): Design of Experiments of Animal Husbandry, Yokendo Co., Tokyo, p. 84.

23) McLaughlan, J. M., and Campbell, J. A. (1969): Methodology of protein evaluation, in Mammalian Protein Metabolism, Vol. III, ed. by Munro, H. N., Academic Press, New York and London, pp. 391-422.

24) Rosenthal, H. L., and Allison, J. B. (1956): Effects of caloric intake on nitrogen balance and organ composition of adult rats. Agric. Food Chem., 4, 792-796.

25) Tanaka, H., and Ogura, M. (1980): Metabolism of serine in growing rats at various dietary fat to carbohydrate ratios. Agric. Biol. Chem., 44, 9-16.

26) Peng, Y. S., Meriza, L. L., Vavich, M. G., and Kemmerer, A. R. (1974): Changes in food intake and nitrogen metabolism of rats while adapting to a low or high protein diet. J. Nutr., 104, 1008-1017.

27) Aguilar, T. S., Harper, A. E., and Benevenga, N. J. (1972): Efficiency of utilization of indispensable amino acids for growth by the rat. J. Nutr., 102, 1199-1208.

28) Brookes, L. M., Owens, F. N., and Garrigus, U. S. (1972): Influence of amino acid level in the diet upon amino acid oxidation by the rat. J. Nutr., 102, 27-36. 